\title{
Usefulness of the procalcitonin test in young febrile infants between 1 and 3 months of age
}

In Sul Lee, MD', Young Jin Park, MD', Mi Hyeon Jin², Ji Young Park, MD', Hae Jeong Lee, MD', Sung Hoon Kim, MD', Ju Suk Lee, MD', Cheol Hong Kim, MD', Young Don Kim, MD', Jun Hwa Lee, MD ${ }^{1}$

Departments of ${ }^{1}$ Pediatrics and ${ }^{2}$ Biostatistics, Samsung Changwon Hospital, Sungkyunkwan University School of Medicine, Changwon, Korea

Purpose: To study the usefulness of the procalcitonin (PCT) test in young febrile infants between 1 and 3 months of age.

Methods: We evaluated the medical records of 336 febrile infants between 1 and 3 months of age who visited the Emergency Department or outpatient department of Samsung Changwon Hospital from May 2015 to February 2017, and analyzed the clinical characteristics between infants in the serious bacterial infection (SBI) group and non-SBI group.

Results: Among the 336 infants, 38 (11.3\%) had definitive SBI (bacteremia, $n=3$; meningitis, $n=1$; urinary tract infection, $\mathrm{n}=34)$. The mean PCT $(6.4 \pm 11.9 \mathrm{ng} / \mathrm{mL})$ and C-reactive protein (CRP) level $(3.8 \pm 2.6 \mathrm{mg} / \mathrm{dL})$, and the absolute neutrophil count (ANC) $(6,984 \pm 4,675)$ for patients in the SBI group were significantly higher than those for patients in the non-SBI group (PCT, $0.3 \pm 1.2 \mathrm{ng} / \mathrm{mL} ; \mathrm{CRP}, 1.3 \pm 1.6$ $\mathrm{mg} / \mathrm{dL} ; \mathrm{ANC}, 4,888 \pm 3,661)$. PCT had lower sensitivity (43.6\%), but higher specificity (92.6\%) and accuracy (86.9\%) than CRP (92.3\%, 25.3\%, and 33.0\%) for identifying SBI. The area under the receiver operating characteristic curves (AUCs) for definitive SBI were PCT 77.0\%, CRP 80.8\%, WBC 56.8\%, ANC $67.8 \%$, and PLT $48.1 \%$. The AUCs for definitive SBI were PCT+CRP 85.4\%, PCT+WBC 77.2\%, PCT+ANC 81.3\%, CRP+WBC $80.1 \%$, and CRP+ANC $81.6 \%$.

Conclusion: Our results suggest that the PCT test or a combination of PCT and CRP tests is a more accurate and specific biomarker to detect and rule out SBls.

Key words: Infant, Fever, Procalcitonin

\section{Introduction}

When infants exhibiting fever and no clear source of infection visit the Emergency Department (ED) or outpatient department (OPD), doctors must diagnose serious bacterial infection (SBI) as soon as possible and determine appropriate next steps. Infants younger than 3 months have the highest risk of SBI such as bacterial meningitis, bacteremia, and urinary tract infection (UTI). Infants between 1 and 3 months of age presenting with fever for unknown reasons are reported to have SBI rates of up to $9 \% .^{1-5)}$ In many studies, the procalcitonin (PCT) test is reported to be superior to other tests in predicting SBI in children. ${ }^{4,6-12)}$ However, some reports indicate that it is no different from other tests. ${ }^{13-17)}$

In this study, we investigated if the PCT test is superior to testing for other biomarkers in predicting SBI in febrile infants with no clear source of infection. In addition, we investigated if the PCT test could better predict SBI when combined with tests for other biomarkers. We focused on infants between 1 and 3 months of age and reviewed their medical records for our assessments.
Corresponding author: Jun Hwa Lee, MD, PhD Department of Pediatrics, Samsung Changwon Hospital, Sungkyunkwan University School of Medicine, 158 Paryong-ro, Masanhoewon-gu, Changwon 51353, Korea

Tel: +82-55-233-5931

Fax: +82-55-233-5329

E-mail: ljh3643@hanmail.net

https://orcid.org/0000-0001-9062-5802

Received: 13 October, 2017

Revised: 14 February, 2018

Accepted: 5 March, 2018
Copyright (C) 2018 by The Korean Pediatric Society

This is an open-access article distributed under the terms of the Creative Commons Attribution NonCommercial License (http://creativecommons.org/ licenses/by-nc/4.0// which permits unrestricted noncommercial use, distribution, and reproduction in any medium, provided the original work is properly cited. 


\section{Materials and methods}

\section{Data collection, study setting, and definitions}

We analyzed the medical records of 336 infant patients who were between 1 and 3 months of age, presented with fever with no clear source of infection, and visited the ED or OPD of Samsung Changwon Hospital from May 2015 to February 2017. We collected the following clinical data from the medical records: patient age, sex, birth history, etiology of fever, duration of fever at home, final diagnosis, highest temperature of fever $\left({ }^{\circ} \mathrm{C}\right)$, PCT level, C-reactive protein (CRP) level, white blood cell (WBC) count, absolute neutrophil count (ANC), platelet (PLT) count, and results from blood, urine, and cerebrospinal fluid (CSF) cultures. Body temperature measured as $38^{\circ} \mathrm{C}$ or higher was defined as fever.

We classified patients into two groups: SBI and non-SBI. In this study, SBI group was defined as (1) bacteremia with pathogenic causative organism grown in blood culture; (2) bacterial meningitis with pathological causative organism grown in CSF culture; or (3) UTI with pyuria (WBC>5/high power field) and a single pathologic agent grown to more than 100,000 colony-forming units/mL in urine collected in a urine bag. Meningitis was defined as the meningism without altered consciousness, with CSF WBC $\geq 5$ / $\mu \mathrm{L} .{ }^{18)}$ We had excluded the following bacteria from the bacteremia group by considering them as a skin flora (e.g., Coagulase negative staphylococci, Bacillus species, viridans streptococci, Micrococcus species). ${ }^{19)}$ We defined non-SBI as proven viral infection, pyuria without bacterial growth on urine culture, meningitis without bacterial growth on CSF culture, respiratory infection or enteritis caused by either virus or bacteria, or fever without localized signs. We excluded Kawasaki disease in this study. The cutoff values were

Table 1. Comparison of demographics between SBI and non-SBI groups $(n=336)$

\begin{tabular}{|c|c|c|c|c|}
\hline Variable & Total $(n=336)$ & Non-SBI $(n=298)$ & $\mathrm{SBI}(\mathrm{n}=38)$ & $P$ value \\
\hline Sex & & & & 0.001 \\
\hline Male & $212(63.1)$ & $179(60.1)$ & $33(86.82)$ & \\
\hline Female & $124(36.9)$ & $119(39.9)$ & $5(13.2)$ & \\
\hline Age at diagnosis (day) & $59.5 \pm 24.5$ & $58.4 \pm 24.6$ & $68.1 \pm 22.5$ & 0.015 \\
\hline Gestational age (wk) $(n=326)$ & $38.8 \pm 1.3$ & $38.7 \pm 1.3$ & $39.2 \pm 1.2$ & 0.061 \\
\hline Pre term & $21(6.2)$ & $21(7.0)$ & $0(0)$ & 0.111 \\
\hline Full term & $298(88.7)$ & $263(88.3)$ & $35(92.1)$ & \\
\hline Post term & $17(5.1)$ & $14(4.7)$ & $3(7.9)$ & \\
\hline Birth weight (g) (n=325) & $3,200 \pm 431$ & $3,185 \pm 432$ & $3,320 \pm 415$ & 0.091 \\
\hline$<2,500$ & $11(3.3)$ & $11(3.7)$ & $0(0)$ & 0.606 \\
\hline $2,500-4,000$ & $302(89.9)$ & 267 (89.6) & $35(92.1)$ & \\
\hline$\geq 4,000$ & $23(6.8)$ & $20(6.7)$ & $3(7.9)$ & \\
\hline Type of delivery $(n=325)$ & & & & 0.416 \\
\hline Cesarean section & $164(50.5)$ & $143(49.7)$ & $21(57.8)$ & \\
\hline Vaginal delivery & $161(49.5)$ & $145(50.3)$ & $16(43.2)$ & \\
\hline Diagnosis & & & & $<0.001$ \\
\hline Fever without localized signs & $167(49.7)$ & $167(56.0)$ & $0(0)$ & \\
\hline Bacteremia & $3(0.9)$ & $0(0)$ & $3(7.9)$ & \\
\hline Meningitis & $49(14.6)$ & $48(16.1)$ & $1(2.6)$ & \\
\hline Respiratory & 65 (19.3) & $65(21.8)$ & $0(0)$ & \\
\hline Gastrointestinal & $14(4.2)$ & $14(4.7)$ & $0(0)$ & \\
\hline Urinary tract infection & $34(10.1)$ & $0(0)$ & $34(89.5)$ & \\
\hline Etc. & $4(1.2)$ & $4(1.3)$ & $0(0)$ & \\
\hline Maximal body temperature $\left({ }^{\circ} \mathrm{C}\right)(\mathrm{n}=331)$ & $38.6 \pm 0.5$ & $38.6 \pm 0.5$ & $39.0 \pm 0.5$ & $<0.001$ \\
\hline Fever duration at home (hr) $(\mathrm{n}=191)$ & $6.3 \pm 6.8$ & $6.1 \pm 6.8$ & $7.7 \pm 6.9$ & 0.336 \\
\hline Admission & & & & 0.343 \\
\hline No & $28(8.3)$ & $27(9.1)$ & $1(2.6)$ & \\
\hline Yes & $308(91.7)$ & $271(90.9)$ & $37(97.4)$ & \\
\hline Length of stay (day) $(n=308)$ & $5.7 \pm 2.6$ & $5.6 \pm 2.4$ & $6.1 \pm 3.9$ & 0.651 \\
\hline
\end{tabular}

Values are presented as number (\%) or mean \pm standard deviation. $\mathrm{SBI}$, serious bacterial infection. 
defined as PCT $\geq 0.5 \mathrm{ng} / \mathrm{mL}, \mathrm{CRP} \geq 0.5 \mathrm{mg} / \mathrm{dL}, \mathrm{WBC}>19,000 / \mu \mathrm{L}$, ANC $>1,300 / \mu \mathrm{L}$, and PLT $\leq 400 \times 10^{3} / \mu \mathrm{L}$, as previous study.

\section{Statistical analysis}

Continuous variables were expressed as mean \pm standard deviation. The independent $t$ test and Mann-Whitney $U$ test were used when comparing definitive SBI and non-SBI. Categorical variables were expressed as number (\%), and either Pearson chi-square test or Fisher exact test was used for comparisons between groups. Sensitivity, specificity, positive predictive value, negative predictive value (NPV), accuracy, and area under the curves (AUCs) for biomarkers of SBI were calculated and compared. The accuracy is the proportion of true results (both true positives and true negatives) among the total number of cases examined. All analyses were conducted using Stata ver. 14.0 (Stata Corporation, College Station, TX, USA) and R 3.3.0 (R Foundation for Statistical Computing, Vienna, Austria; http://www.R-project.org) at a significance level of 0.05 .

\section{Ethics statement}

Ethical approval for this retrospective study was obtained from the Institutional Review Board of Samsung Changwon Hospital and informed consent was waived (approval number: SCMC2017-08009).

\section{Results}

We analyzed the medical record of 336 febrile infants between 1 and 3 months of age with no clear source of infection. Of the
336 febrile infants, 212 (63.1\%) were male. Mean age at diagnosis was $59.5 \pm 24.5$ days, gestational age was $38.8 \pm 1.3$ weeks, and birth weight was $3,200 \pm 431 \mathrm{~g}$. Type of delivery of SBI group did not differ from that of non-SBI group (cesarean section 50.5\% vs. vaginal delivery $49.5 \%, P=0.659)$. However, the maximal body temperature of SBI group $\left(39.0^{\circ} \mathrm{C} \pm 0.5^{\circ} \mathrm{C}\right)$ was higher than that of non-SBI (38.6 $\left.{ }^{\circ} \mathrm{C} \pm 0.5^{\circ} \mathrm{C}, P<0.05\right)$. Ninety-five infants (28.3\%) visited the hospital OPD and 241 (71.7\%) visited the ER. Three hundred eight infants $(91.7 \%)$ were admitted. The mean length of stay was $5.7 \pm 2.6$ days. The onset of fever until arrival at the hospital was clearly noted in 191 patients. Of 191 patients, the mean duration of fever at home was $6.3 \pm 6.8$ hours. Among the 336 cases, 38 (11.3\%) were classified as definitive SBI. Of the $38 \mathrm{SBI}$ patients, 3 patients were UTI sepsis caused by Escherichia coli, 1 patient was meningitis caused by Streptococcus agalactiae, and 34 patients were UTI (Table 1). Of the 34 patients of UTI, E. coli was the most commonly found pathogen, appearing in 33 cases; S. agalactiae was found in 1 case. There were no cases of definitive SBI with complication.

Mean laboratory values in SBI patients were PCT $6.4 \pm 11.9 \mathrm{ng} /$ $\mathrm{mL}$, CRP 3.8 $\pm 2.6 \mathrm{mg} / \mathrm{dL}, \mathrm{WBC} 12,882 \pm 6,568 / \mu \mathrm{L}$, ANC 6,984 $\pm 4,675 /$ $\mu \mathrm{L}$, and PLT $382.5 \pm 102.1 \times 10^{3} / \mu \mathrm{L}$. In comparison, the mean values in the non-SBI group were PCT $0.3 \pm 1.2 \mathrm{ng} / \mathrm{mL}$, CRP $1.3 \pm 1.6 \mathrm{mg} /$ dL, WBC 11,591 $\pm 5,299 / \mu \mathrm{L}$, ANC 4,888 $\pm 3,661 / \mu \mathrm{L}$, and PLT $397.5 \pm$ $121.1 \times 10^{3} / \mathrm{\mu L}$. There were significant differences in PCT, CRP, and ANC between SBI and non-SBI groups $(P<0.001)$ (Table 2).

The sensitivity of the SBI group was PCT 43.6\%, CRP 92.3\%, WBC 15.4\%, ANC 97.4\%, and PLT 51.3\%. As well, the specificity of the SBI group was PCT 92.6\%, CRP 25.3\%, WBC 91.9\%, ANC 5.1\%, and PLT 52.2\%.

However, the accuracy of the SBI group was $86.9 \%$ for PCT

Table 2. Comparison of laboratory characteristics between SBI and non-SBI groups $(n=336)$

\begin{tabular}{|c|c|c|c|c|}
\hline Variable & Total $(n=336)$ & Non-SBI $(n=298)$ & $\mathrm{SBI}(\mathrm{n}=38)$ & $P$ value \\
\hline Procalcitonin (ng/mL) & $1.0 \pm 4.6$ & $0.3 \pm 1.2$ & $6.4 \pm 11.9$ & $<0.001$ \\
\hline$<0.5$ & $297(88.4)$ & $276(92.6)$ & $21(55.3)$ & $<0.001$ \\
\hline$\geq 0.5$ & 39 (11.6) & $22(7.4)$ & $17(44.7)$ & \\
\hline C-reactive protein (mg/dL) & $1.6 \pm 1.9$ & $1.3 \pm 1.6$ & $3.8 \pm 2.6$ & $<0.001$ \\
\hline$<0.5$ & 78 (23.2) & 75 (25.2) & $3(7.9)$ & 0.018 \\
\hline$\geq 0.5$ & $258(76.8)$ & $223(74.8)$ & $35(92.1)$ & \\
\hline 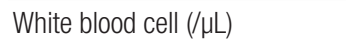 & $11,737 \pm 5,461$ & $11,591 \pm 5,299$ & $12,882 \pm 6,568$ & 0.185 \\
\hline$\leq 19,000$ & $306(91.1)$ & $274(92.0)$ & $32(84.2)$ & 0.115 \\
\hline$>19,000$ & $30(8.9)$ & $24(8.1)$ & $6(15.8)$ & \\
\hline Absolute neutrophil count $(/ \mu \mathrm{L})$ & $5,125 \pm 3,839$ & $4,888 \pm 3,661$ & $6,984 \pm 4,675$ & $<0.001$ \\
\hline$\leq 1,300$ & $16(4.8)$ & $15(5.0)$ & $1(2.6)$ & $>0.999$ \\
\hline$>1,300$ & $320(95.2)$ & $283(95.0)$ & 37 (97.4) & \\
\hline Platelet $\left(\times 10^{3} / \mu \mathrm{L}\right)$ & $395.8 \pm 119.1$ & $397.5 \pm 121.1$ & $382.5 \pm 102.1$ & 0.708 \\
\hline$\leq 400$ & $174(51.8)$ & $156(52.3)$ & 18 (47.4) & 0.563 \\
\hline$>400$ & $162(48.2)$ & $142(47.7)$ & 20 (52.6) & \\
\hline
\end{tabular}

Values are presented as mean \pm standard deviation or number (\%).

$\mathrm{SB}$, serious bacterial infection. 
Table 3. Sensitivity, specificity, positive predictive value, negative predictive value, accuracy for definite SBI

\begin{tabular}{|c|c|c|c|c|c|}
\hline Variable & Sensitivity (\%) & Specificity (\%) & PPV (\%) & NPV (\%) & 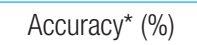 \\
\hline Procalcitonin (0.5 ng/mL) & $43.6(27.8-60.4)$ & $92.6(89.0-95.3)$ & $43.6(27.8-60.4)$ & $92.6(89.0-95.3)$ & $86.9(82.8-90.3)$ \\
\hline C-reactive protein (0.5 mg/dL) & $92.3(79.1-98.4)$ & $25.3(20.4-30.6)$ & $14.0(10.0-18.8)$ & $96.2(89.2-99.2)$ & $33.0(28.0-38.3)$ \\
\hline White blood cell $(19,000 / \mu \mathrm{L})$ & $15.4(5.9-30.5)$ & $91.9(88.2-94.8)$ & $20.0(7.7-38.6)$ & $89.2(85.2-94.5)$ & $83.0(78.6-86.9)$ \\
\hline Absolute neutrophil count $(1,300 / \mu \mathrm{L})$ & $97.4(86.5-99.9)$ & $5.1(2.9-8.2)$ & $11.9(8.5-15.9)$ & $93.8(69.8-99.8)$ & $15.8(12.0-20.1)$ \\
\hline Platelet $\left(400 \times 10^{3} / \mu \mathrm{L}\right)$ & $51.3(34.8-67.6)$ & $52.2(46.3-58.0)$ & $12.3(7.7-18.4)$ & $89.1(83.5-93.3)$ & $52.1(46.6-57.5)$ \\
\hline \multicolumn{6}{|l|}{ Combination } \\
\hline $\mathrm{PCT}+\mathrm{CRP}$ & $38.5(23.4-55.4)$ & $93.6(90.2-96.1)$ & $44.1(27.2-62.1)$ & $92.1(88.4-94.8)$ & $87.2(83.2-90.6)$ \\
\hline $\mathrm{PCT}+\mathrm{WBC}$ & $10.3(2.9-24.2)$ & $98.3(96.1-99.5)$ & $44.4(13.7-78.8)$ & $89.3(85.4-92.4)$ & $88.1(84.1-91.4)$ \\
\hline $\mathrm{PCT}+\mathrm{ANC}$ & $41.0(25.6-57.9)$ & $92.9(89.4-95.6)$ & $43.2(27.1-60.5)$ & $92.3(88.7-95.1)$ & $86.9(82.8-90.3)$ \\
\hline $\mathrm{CRP}+\mathrm{WBC}$ & $15.4(5.9-30.5)$ & $91.9(88.2-94.8)$ & $20.0(7.7-38.6)$ & $89.2(85.2-92.5)$ & $83.0(78.6-86.9)$ \\
\hline $\mathrm{CRP}+\mathrm{ANC}$ & $89.7(75.8-97.1)$ & $28.6(23.5-34.1)$ & $14.2(10.1-19.2)$ & 95.5 (88.9-98.8) & $35.7(30.6-41.1)$ \\
\hline
\end{tabular}

SBI, serious bacterial infection; PPV, positive predictive value; NPV, negative predictive value; PCT, procalcitonin; CRP, C-reactive protein; WBC, white blood cell; ANC, absolute neutrophil count.

${ }^{*}$ Accuracy=(number of true positive cases+true negative cases)/total number of cases.
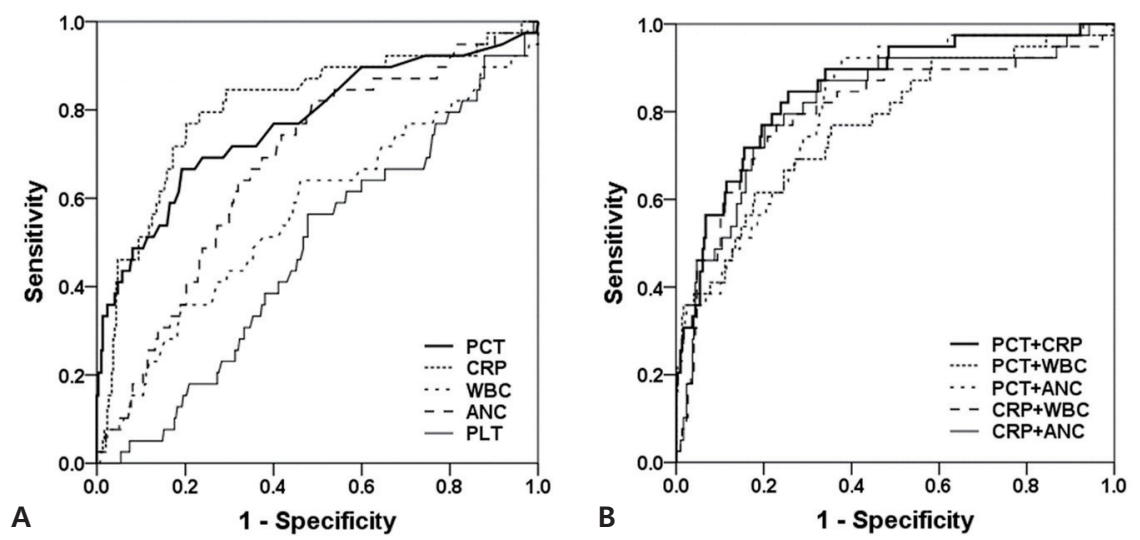

Fig. 1. (A) Receiver operating characteristic curves of single biomarkers for serious bacterial infection. (B) Receiver operating characteristic curves of combined biomarkers. PCT, procalcitonin; CRP, C-reactive protein; WBC, white blood cell; ANC, absolute neutrophil count; PLT, platelet.

followed by $83.0 \%$ for WBC. If combined the biomarkers, $\mathrm{PCT}+\mathrm{WBC}$ was revealed as the highest specificity and accuracy $(98.3 \%$ and 88.1\%), followed by PCT+CRP (93.6\% and 87.2\%) and PCT+ANC (92.9\% and 86.9\%, Table 3).

Predicted AUCs on receiver operating characteristic (ROC) curve were $77.0 \%$ for PCT and $80.8 \%$ for CRP, indicating that PCT and CRP were not different. The AUCs for biomarker combinations were 85.4\% for PCT+CRP, 77.2\% for PCT+WBC, 81.3\% for PCT+ANC, $80.1 \%$ for CRP+WBC, and $81.6 \%$ for CRP+ANC. The highest AUC was confirmed as combination with PCT and CRP whether single biomarker or two combined biomarkers (Fig. 1). The cutoff values on our ROC curve were confirmed as PCT $0.5 \mathrm{ng} / \mathrm{mL}$, CRP $0.49 \mathrm{mg} /$ $\mathrm{dL}, \mathrm{WBC} 19,500 / \mu \mathrm{L}$, ANC $1,300 / \mu \mathrm{L}$, and PLT $400.5 \times 10^{3} / \mu \mathrm{L}$.

\section{Discussion}

The probability of SBI without an apparent source is reported to be up to 12\% for infants less than 28 days old and up to $9 \%$ for infants between 1 and 3 months of age. ${ }^{4)}$ Decades of research and debate have been dedicated not only to determining the likelihood of SBI causing fever in infant, but also to establishing treatment guidelines for such instances. Clinical examination alone is not sufficient to exclude SBI as a diagnosis. The Philadelphia and Rochester Criteria in combination with laboratory screening test results are used to assess SBI in patients. Sensitivity is reported to be $98 \%$ for the Philadelphia Criteria and 92\% for the Rochester; reported NPVs are 97.1\% and 97.3\%, respectively. ${ }^{20,21)}$ However, because accurately determining SBI in febrile infants is difficult, testing for several clinical biomarkers is used in conjunction with routine laboratory evaluation and clinical suspicion. The additional biomarker tests include those of peripheral WBC count, ANC, and CRP, which have 
sensitivities ranging from 45 to $79 \%$ and specificities ranging from 78\% to $79 \%{ }^{4)}$

In 1993, Assicot et al. (quoted from ${ }^{22)}$ ) reported that patients with SBI had high serum concentration of PCT, a calcitonin peptide without hormonal function. During infection or inflammation, plasma PCT concentration is known to both increases and return to normal more rapidly than CRP level. ${ }^{23)} \mathrm{PCT}$ level was also observed to increase faster than CRP level 6 hours after the onset of severe inflammatory response syndrome. ${ }^{24)}$ For these reasons, the PCT test is considered a useful tool in early diagnosis of infection or inflammations. Other studies have investigated whether PCT is a useful biomarker to distinguish between viral infection and SBI. PCT was found to distinguish between bacterial and viral meningitis ${ }^{8,25,26)}$ and to identify SBI in infants more accurately than classic screening tests. ${ }^{6}$ However, one report noted that PCT level might not be reliable in diagnosing bacterial meningitis after neurosurgery ${ }^{16)}$ Another report found that serum PCT concentration is not a good indicator of bacterial ventriculoperitoneal shunt infection. ${ }^{17)}$ In pediatric patients visiting emergency departments or primary care, PCT testing was found to be superior to measuring WBC count, but similar to measuring CRP. ${ }^{15)}$

Several Korean studies have focused on PCT. Hur et al. ${ }^{27)}$ performed the PCT and CRP simultaneously on single blood samples from 1,270 patients with blood culture-positive sepsis. They reported that the diagnostic utility of the PCT was superior to evaluation of CRP level. However, in diagnosing neonatal bacterial infection, the PCT was found to be more expensive, with comparably acceptable specificity and similar or better sensitivity than the $\mathrm{CPR}{ }^{28)}$ Serum PCT level has been reported as a highly effective early diagnostic marker for neonatal bacterial infection, but is not as reliable a marker as CRP. ${ }^{29,30)}$ Kim et al. ${ }^{31)}$ reported that there is no diagnostic value in measuring serum PCT concentration determine bacterial infection in febrile infants 6 months of age or younger. Yang et al. ${ }^{32)}$ reported similar sensitivities and specificities for serum CRP and serum PCT in diagnosing acute pyelonephritis (APN) in infants 12 months of age or younger. However, the sensitivity and specificity for APN diagnosis increased when PCT was combined with CRP and erythrocyte sedimentation rate.

In this study, sex and age at diagnosis in SBI group differed from those of non-SBI group because of large percentage of UTI or UTI sepsis in SBI group. Of 38 SBI patients, 34 had UTI and 3 had UTI sepsis. 76.5\% of UTI group and 66.6\% of bacteremia were 61-90 days old infants. Also, UTI were frequently diagnosed in male in infants.

This study had some limitations. First, we could not represent the entire infant population in Korea when assessing SBI, because this study was conducted using medical records from a single hospital. Second, determining the severity of SBI was difficult because few were found to have sepsis and meningitis among the definitive SBI patients. Third, we collected urine using urine bags rather than catheterization, increasing the likelihood of contamination.

Even with these limitations, our study offers a significant comparative analysis of biomarkers that can predict SBI in infants between 1 and 3 months of age who are vulnerable to infection and who visit the pediatric $\mathrm{ED}$ with fever.

In conclusion, PCT was shown as lower sensitivity than CRP, but higher specificity and accuracy than CRP for identifying SBI in febrile infants between 1 and 3 months of age. A combination of PCT and CRP showed the highest AUC than the other combination of biomarkers. Therefore, we suggested the predictor of SBIs for PCT or combination of PCT and CRP which were more accurate and specific biomarker to rule out the SBI.

\section{Conflicts of interest}

No potential conflict of interest relevant to this article was reported.

\section{References}

1. Baraff LJ. Outpatient management of fever in selected infants. N Engl J Med 1994;330:938-9.

2. Baskin MN. The prevalence of serious bacterial infections by age in febrile infants during the first 3 months of life. Pediatr Ann 1993; 22:462-6.

3. Byington CL, Enriquez FR, Hoff C, Tuohy R, Taggart EW, Hillyard DR, et al. Serious bacterial infections in febrile infants 1 to 90 days old with and without viral infections. Pediatrics 2004;113:1662-6.

4. Maniaci V, Dauber A, Weiss S, Nylen E, Becker KL, Bachur R. Procalcitonin in young febrile infants for the detection of serious bacterial infections. Pediatrics 2008;122:701-10.

5. Tan TQ. Procalcitonin in young febrile infants for the detection of serious bacterial infections: is this the "holy grail"? Pediatrics 2008; 122:1117-8.

6. Mahajan P, Grzybowski M, Chen X, Kannikeswaran N, Stanley R, Singal B, et al. Procalcitonin as a marker of serious bacterial infections in febrile children younger than 3 years old. Acad Emerg Med 2014;21:171-9.

7. Bustos BR, Padilla PO. Predictive value of procalcitonin in children with suspected sepsis. Rev Chil Pediatr 2015;86:331-6.

8. Konstantinidis T, Cassimos D, Gioka T, Tsigalou C, Parasidis T, Alexandropoulou I, et al. Can procalcitonin in cerebrospinal fluid be a diagnostic tool for meningitis? J Clin Lab Anal 2015;29:169-74.

9. Zhu F, Jiang Z, Li WH, Wei HY, Su GD. Clinical significance of serum procalcitonin level monitoring on early diagnosis of severe pneumonia on children. Eur Rev Med Pharmacol Sci 2015;19:4300-3.

10. Ivaska L, Elenius V, Mononen I, Ruuskanen 0, Peltola V. Discrepancies between plasma procalcitonin and C-reactive protein levels are common in acute illness. Acta Paediatr 2016;105:508-13.

11. Milcent K, Faesch S, Gras-Le Guen C, Dubos F, Poulalhon C, Badier I, et al. Use of procalcitonin assays to predict serious bacterial infection in young febrile infants.. JAMA Pediatr 2016;170:62-9.

12. Jacobs DM, Holsen M, Chen S, Fusco NM, Hassinger AB. Procalcitonin to Detect Bacterial Infections in Critically Ill Pediatric Patients. Clin Pediatr (Phila) 2017;56:821-7. 
13. Thayyil S, Shenoy M, Hamaluba M, Gupta A, Frater J, Verber IG. Is procalcitonin useful in early diagnosis of serious bacterial infections in children? Acta Paediatr 2005;94:155-8.

14. Manzano S, Bailey B, Gervaix A, Cousineau J, Delvin E, Girodias JB. Markers for bacterial infection in children with fever without source. Arch Dis Child 2011;96:440-6.

15. Thompson M, Van den Bruel A, Verbakel J, Lakhanpaul M, HajHassan T, Stevens R, et al. Systematic review and validation of prediction rules for identifying children with serious infections in emergency departments and urgent-access primary care. Health Technol Assess 2012;16:1-100.

16. Choi SH, Choi SH. Predictive performance of serum procalcitonin for the diagnosis of bacterial meningitis after neurosurgery. Infect Chemother 2013;45:308-14.

17. Tomio R, Akiyama T, Shibao S, Yoshida K. Procalcitonin as an early diagnostic marker for ventriculoperitoneal shunt infections. Surg Infect (Larchmt) 2013;14:433-6.

18. Kelly C, Sohal A, Michael BD, Riordan A, Solomon T, Kneen R, et al. Suboptimal management of central nervous system infections in children: a multi-centre retrospective study. BMC Pediatr 2012;12: 145.

19. Park JY, Yun KW, Kang HJ, Park KD, Shin HY, Lee HJ, et al. Etiology of bacteremia in children with hemato-oncologic diseases from a single center from 2011 to 2015. Pediatr Infect Vaccine 2017;24:71-8.

20. Jaskiewicz JA, McCarthy CA, Richardson AC, White KC, Fisher DJ, Dagan R, et al. Febrile infants at low risk for serious bacterial infection--an appraisal of the Rochester criteria and implications for management. Febrile Infant Collaborative Study Group. Pediatrics 1994;94:390-6.

21. Garra G, Cunningham SJ, Crain EF. Reappraisal of criteria used to predict serious bacterial illness in febrile infants less than 8 weeks of age. Acad Emerg Med 2005;12:921-5.

22. Chiesa C, Pacifico L, Mancuso G, Panero A. Procalcitonin in pedia- trics: overview and challenge. Infection 1998;26:236-41.

23. Schroeder S, Hochreiter M, Koehler T, Schweiger AM, Bein B, Keck FS, et al. Procalcitonin (PCT)-guided algorithm reduces length of antibiotic treatment in surgical intensive care patients with severe sepsis: results of a prospective randomized study. Langenbecks Arch Surg 2009;394:221-6.

24. Rey C, Los Arcos M, Concha A, Medina A, Prieto S, Martinez P, et al. Procalcitonin and C-reactive protein as markers of systemic inflammatory response syndrome severity in critically ill children. Intensive Care Med 2007;33:477-84.

25. Abdelkader NA, Mahmoud WA, Saber SM. Serum procalcitonin in Egyptian patients with acute meningitis and a negative direct cerebrospinal fluid examination. J Infect Public Health 2014;7:106-13.

26. Prasad R, Kapoor R, Mishra OP, Srivastava R, Kant Singh U. Serum procalcitonin in septic meningitis. Indian J Pediatr 2013;80:365-70.

27. Hur M, Moon HW, Yun YM, Kim KH, Kim HS, Lee KM. Comparison of diagnostic utility between procalcitonin and C-reactive protein for the patients with blood culture-positive sepsis. Korean J Lab Med 2009;29:529-35.

28. Kim EK, Lee BS, Lee JA, Jo HS, Park JD, Kim BI, et al. Clinical availability of serum procalcitonin level in the diagnosis of neonatal bacterial infection. J Korean Soc Neonatol 2001;8:211-21.

29. Park IH, Lee SH, Yu ST, Oh YK. Serum procalcitonin as a diagnostic marker of neonatal sepsis. Korean J Pediatr 2014;57:451-6.

30. Kim J, Jang M, Koo SH, Kwon KC. Usefulness of procalcitonin in the diagnosis of early neonatal bacterial infection. Lab Med Online 2014; 4:85-90.

31. Kim NH, Kim JH, Lee TJ. Diagnostic value of serum procalcitonin in febrile infants under 6 months of age for the detection of bacterial infections. Korean J Pediatr Infect Dis 2009;16:142-9.

32. Yang EA, Park JS, Cho MH, Lee SW. Clinical usefulness of serum procalcitonin as a biomarker of acute pyelonephritis. Korean J Nephrol 2010;29:716-24. 